- 综述・

\title{
植物区系地理研究现状及发展趋势
}

\author{
孙 航 ${ }^{*}$ 邓 涛 ${ }^{1}$ 陈永生 ${ }^{1,2}$ 周 卓 ${ }^{1}$ \\ 1 (中国科学院昆明植物研究所东亚植物多样性与生物地理学重点实验室, 昆明 650201) \\ 2 (中国科学院大学, 北京 100049)
}

\begin{abstract}
摘要: 中国植物区系地理学在植物区系的调查、分布区类型的划分和研究、植物区系分区以及区域植物区系的分 析等方面有了丰富的研究积累。但这些研究绝大部分是利用传统方法对植物物种或分类群数据进行统计分析, 因 此仍处于对区系现象的认识和描述阶段, 缺乏空间格局形成过程、形成机制方面的深入探索。此外, 还存在植物 区系调查薄弱甚至是空白的地区，许多植物标本缺乏详细或精确的信息，植物物种鉴定的准确性还需要提高。同 时, 随着植物区系地理以及相关学科的快速发展, 植物区系地理学的研究步入了多学科交叉融合、综合研究分析 的阶段, 学科界限趋于模糊。一方面, 利用物种信息数据库, 融合生态学、古植物学以及地质历史等探讨区系空间 地理格局的成因; 另一方面, 结合系统发育、分子系统进化(甚至到进化基因组学)、生命之树以及分子生物地理学 等揭示区系的起源和进化; 同时, 各学科的快速发展, 产生了大量的数据, 新的分析方法或新理论的出现和运用, 使植物区系地理研究也进入到了大数据时代, 进而使得植物区系地理研究由定性的现象认识和描述, 逐步深入到 了定量地解释区系现象和探索其形成机制的时代。
\end{abstract}

关键词: 植物区系地理; 区系调查; 学科交叉; 生态学; 分子系统学; 生物地理学; 大数据

\section{Current research and development trends in floristic geography}

\author{
Hang Sun ${ }^{1 *}$, Tao Deng ${ }^{1}$, Yongsheng Chen ${ }^{1,2}$, Zhuo Zhou ${ }^{1}$ \\ 1 Key Laboratory for Plant Diversity and Biogeography of East Asia, Kunming Institute of Botany, Chinese Academy of \\ Sciences, Kunming 650201 \\ 2 University of Chinese Academy of Sciences, Beijing 100049
}

\begin{abstract}
This paper summarizes the research status, existing issues, and trends in floristic geography. There is now a wealth of research accumulation on floristic investigations, distribution types of genera, floristic regions, and regional floristic analysis. It is also noted that most of these studies utilize simple statistical analyses, comparative studies, traditional methods, and single subjects, to provide a basic understanding and description of the floristic phenomenon, which is lacking spatial pattern formation processes and detailed exploration of formation mechanisms. Additionally, there are still some weak and non-existent areas of botanical investigation. Many existing specimens lack detailed or accurate information and the precise identification of plant species also needs to be much improved. At the same time, when analyzing the development trends of floristic geography, with the rapid development of related disciplines, including the development of biogeography and analysis methods and improvements, floristic geography research is an area of multidisciplinary integration, comprehensive research, and analysis. On the one hand, using database information, and combining ecology, paleobotany, and geology can allow us to probe into spatial pattern formation. On the other hand, combining phylogenetics, the tree of life, and molecular biogeography allow us to reveal floristic origins and evolution. The rapid development of various disciplines has given rise to a large amount of data, meanwhile, the emergence and application of new analytical methods and theories incorporate big data into floristic geography research, which will enhance qualitative understanding and description, and allow us to further explore the mechanisms of formation quantitatively.
\end{abstract}

收稿日期: 2016-09-20; 接受日期: 2016-11-07

基金项目：国家自然科学基金重大项目(31590823)和中科院战略性 B 类先导科技专项(XDB03030106)

* 通讯作者 Author for correspondence. E-mail: sunhang@mail.kib.ac.cn 
Key words: floristic geography; floristic investigation; comprehensive research; ecology; molecular phylogenetics; biogeography; big data

\section{1 前言}

植物区系地理学(Floristic Geography)是植物地 理学或生物地理学的重要分支学科, 是一门主要研 究全球或某一地区所有植物种类的组成、现代和过 去分布规律以及起源进化和演变历史的科学(王荷 生, 1992)。在20世纪中叶以前, 胡先骕、刘慎谔、 李惠林等开启了中国植物地理学研究, 为中国植物 区系地理的研究奠定了前期的基础。到了20世纪中 后期, 吴征镒(1965)发表《中国植物区系的热带亲 缘》一文, 成为中国植物区系地理学研究的开端和 标志。此后, 以吴征镒为代表的植物学家对中国植 物区系地理进行了全面系统的研究, 植物区系地理 学的研究进入了一个繁盛的阶段。同时, 《中国植 物志》和地方植物志的编研也进展显著, 特别是进 入 21 世纪以来, 《中国植物志》中文版 80 卷 126 册 (1959-2004)全部出版, 之后中美合作的Flora of China (Vols.1-25)也相继完成; 地区植物志方面, 目 前为止有 26 个省市已经完成编研, 北京、台湾、内 蒙古和宁夏等地区甚至还出了第二版或修订版，重 庆市植物则由《四川植物志》记载; 除湖南、江西 和广西3省尚未完成以及陕西和吉林两省尚未开展 编研外, 总体上讲中国的植物种类调查已在省市区 一级基本完成或至少完成一次记载(马金双，2011), 所有这些为中国植物区系深入细致的研究奠定了 重要的基础。最新统计数字表明, 迄今为止, 中国 植物区系共有种子植物259科2,935 属29,818 余种(恩 格勒系统), 其中特有属 256 个, 特有种 $15,000-18,000$ 种, 是北半球拥有植物区系最为丰富 的国家。吴征镒等按照地理成分和发生成分相结合 的原则, 将中国种子植物 3,116属(1983年的数据)划 分为 15 大分布区类型和 31 个变型 (吴征捡和王荷生, 1983; 吴征钑，1991); 随后吴征镒等(2003b)又提出 了世界种子植物的分布区类型系统, 将世界种子植 物的科划分为了 18 大分布型, 中国有 15 个大分布 型, 74 个变型(中国有 38 个), 同时又进一步完善了种 子植物属的分布区系统, 将中国属的分布区类型划 分为 15 大类型和 35 个亚型(吴征镒等, 2003a, 2006)。
与此同时，吴征镒等(1979)在其原来区划的基础上, 对中国植物区系区划提出了新的草案，将中国植物 区系分为 4 个植物区 $($ 古热带植物区、东亚植物区、 泛北极植物区、古地中海植物区), 7 个亚区，以及 24 个地区和49个亚地区 $(\mathrm{Wu} \& \mathrm{Wu}, 1998$; 吴征篮和孙 航，2014)。因此，中国植物区系的组成、地理分布 格局以及性质特征和植物区系分区已初步弄清。具 体如下:

(1)在植物区系的调查和采集方面。到目前为止 我国采集并数字化的植物标本近一千万份 (NSII, http://www. nsii.org.cn/), 基本覆盖了我国所有的山 地。对其中的 500 万份数字化的植物标本进行分析, 结果显示平均每个县约4,138份记录, 1,895 份记录 $/ \mathrm{km}^{2}$ 。尤其以青藏高原一横断山区、云贵高原、秦巴、 武陵山、罗霄山脉、南岭等区域采集最为密集(Yang et al, 2014)。随着调查的深入以及研究手段的进步, 近 10 年来每年平均约有 12 个新分类群发表。

(2)中国植物区系的基本特征和分区框架已完 成。除了植物志等著作外, 一系列区系地理研究的 重要的专著、专集相继出版或修订，如《中国自然 地理一一植物地理》(吴征镒和王荷生, 1983)、《中 国种子植物区系地理》(吴征镒等, 2011)、《种子植 物分布区类型及其起源与分化》 (吴征镒等, 2006)、

《种子植物科属地理》(路安民, 1999)、《中国被子 植物科属综论》(吴征镒等, 2003a)、《中国植物地理》 (应俊生和陈梦玲, 2011)、《中国植物区系地理》(吴 征镒和孙航, 2014)、《中国植物区系与植被地理》(陈 灵芝等, 2015)、Plants of China (Hong \& Blackmore, 2013)等，基本弄清了中国植物区系的家底和区系 组成特征及地理分布格局。此外，区域植物区系也 有了系统的研究，如东北植物区系(傅沛云等, 1995; 曹伟等，1995)、华北植物区系(王荷生等, 1995; 王 荷生, 1997)、华中植物区系(祁承经等, 1995)、华东 植物区系(刘昉勋等, 1995)、西北荒漠植物区系(刘 媖心, 1995; 尹林克, 1997; 潘晓玲等, 2003)、华夏植 物区系(张宏达, 1980, 1994)、黄土高原植物区系(张 文辉等, 2002)、滇黔桂地区(方瑞征等, 1995)、西藏 植物区系(吴征镒，1987)、青藏高原植物区系(武素 
功等, 1995)、云南植物区系(李锡文, 1995a, b; 朱华, 2008)、中国南部热带植物区系(朱华, 2017), 横断山 植物区系(Wu, 1988; 李锡文和李捷, 1993)、秦岭植 物区系(应俊生, 1994)、台湾植物区系(Hsieh, 2002)、 南海岛屿植物区系(邢福武等, 1993，1996; 吴德邻 等，1996) 等, 以及特有区系 (王荷生和张镱锂, 1994a，b；应俊生，1996; 郝日明，1997; Wu et al, 2007)等。此外, 宋之琛等(1983)、陶君容(1992, 2000) 也研究了中国的古植物区系。

科属植物地理研究方面, 在 2000 年以前, 科属 地理格局的研究主要是基于传统的系统进化并结 合地理分布式样来进行综合分析, 比较有代表性的 是路安民(1999)主编的《种子植物科属地理》, 收录 了中国 45 个代表性类群地理分布格局的研究, 为探 讨中国植物区系的起源提供了重要资料。但由于当 时研究方法的局限以及研究资料的缺乏, 种属植物 地理的研究参差不齐。随着分子系统学的发展, 科 属植物地理学的研究进入了崭新的阶段, 产生了分 子生物地理学, 再结合化石资料和地质学证据发展 成了历史生物地理学, 现今已逐步进入到了基因组 时代(Wen et al, 2013)。到目前为止已有 300 个以上的 类群或支系不同程度地开展了分子生物地理学的 研究。此外, 近来谱系地理学的研究也快速发展, 为探讨植物区系的冰期避难所以及种群分化历史 提供了直接的证据(Qiu et al, 2011; Liu et al, 2012), 迄今为止, 已有 120 余个物种开展了谱系地理学的 研究, 为深入探讨中国植物区系的起源、时间和迁 移途径和地理格局的形成提供了重要的基础资料。

在植物区系数据库建设方面, 目前国内提供植 物区系信息的数据库已近 20 个, 比较有影响力的如 中 国数字植物标本馆 $(\mathrm{CVH}$, http://www.cvh.org.cn/)、国家标本资源共享平台 (NSII)、中国在线植物志(http://www.eflora.cn)、Flora of China (FOC, http://www.floraofchina.org)、中国植 物物种信息数据库 (http://db.kib.ac.cn/eflora)、中国 植物图像库(PPBC) (http://www.plantphoto.cn)等。随 着计算机信息技术的发展, 植物物种以及标本等信 息的数字化工作的开展, 极大地丰富了植物区系地 理研究的基础资料, 同时也使得植物区系地理逐步 从定性转入更深入细致的定量研究。

综上, 经过几代植物学家的努力, 中国作为一 个生物多样性大国, 在植物区系的基本特征、分区、
起源等研究方面已积累了丰富的资料, 不仅推动了 植物区系或植物多样性的起源形成演变等基础理 论问题的深入研究, 也为生物多样性的保护提供了 重要的理论基础和实践指导。

\section{2 存在的问题}

虽然经过几代植物学工作者的研究, 中国植物 区系的组成、地理格局等已基本清楚，但这些研究 仍处于对现象的描述阶段, 绝大部分仍然是基于基 础数据, 利用传统方法进行统计分析, 缺乏整合物 种地理格局、环境因子、地质历史或系统发育等信 息, 定量分析与探究区系构成以及地理分布格局成 因的研究, 还有许多植物区系调查薄弱甚至是空白 的地区。具体表现如下。

\section{1 植物区系分析和调查还需要补充和完善}

中国植物区系的调查还存在空白或薄弱地区, 基本的物种数据还需补充和完善, 例如, 许多标本 记录信息不够详细，拥有GPS记录的则更少(初步统 计仅占全部标本的 $10 \%$ 左右), 许多标本采集集中在 20世纪50-80年代以及本世纪初的2000-2009年, 一 些区系研究的物种数据仅引自文献或是来源于很 少的标本记录, 还有许多类群的分类学研究需要 深入。

近 10 年来, 我国高等植物平均每年有 120 余个 新种发表, 也从一方面表明, 植物区系的调查以及 植物分类学研究还需要继续深入。另外, 标本资料 的正确鉴定也是植物区系地理研究的瓶颈。近 20 年 来, 随着植物考察的深入和扩大, 我国植物标本馆 标本的采集量有了很大幅度的增加, 但被分类学专 家鉴定的标本数量非常有限, 并且许多标本鉴定可 能是错误的。这事实上是全球性的问题。Goodwin 等(2015)以姜科植物为例, 指出在热带植物标本中 约有 $50 \%$ 的标本鉴定是不正确的, 温带植物的标本 可能也存在同样的情况。在中国虽然没有进行过调 查分析，但错误鉴定和没有被鉴定的标本可能也接 近该比例。这势必会影响到对标本资料的应用和数 据库资料的准确性。

\section{2 植物分布区类型需要进一步补充和修订}

虽然吴征镒等 $(2006,2011)$ 进一步修订和完善 了中国属的分布区类型(划分为 15 大类型和 35 个亚 型), 但最近的植物分类学特别是结合分子系统学 的研究表明, 不少科属的分类发生了变化, 如小属 
的合并、大属的拆分或种在属间的转移等, 使得其 原来界定的分布区发生了变化, 初步统计大约有 733 个属需要重新界定分布范围。另外随着区系调 查的深入，一些新的类群或新的地理分布记录被发 现和发表，如丹霞兰属(Danxiaorchis)、假合头菊属 (Parasyncalathium)、宽昭木属(Foonchewia)、征镒 麻属(Zhengyia)等, 这些新类群需要补充分布信息。 因此, 我们还需要根据最新的区系调查及分类研究 成果完善或修订中国植物属级的分布区类型。

在植物区系区划上，区系的分区仍然是框架性 的, 主要的依据还是特有性及其等级的高低, 如, “区(realm or kingdom)”主要是依据特有高分类阶元 如科、亚科和族等, “地区(region)”则依据特有属和 大量的特有种。区划的阶元越低, 特有分类单位的 分类等级越低, 如到了“小区 (district)”, 则可能主 要是依据种下特有等级如亚种(Takhtajan, 1986)。

当然, 在区系区划中也考虑了植被的因素。吴 征镒等(2011)在中国植物区系区划中特别是确定地 区和亚地区的界限时还考虑了植被区划。但这些区 划原则都是定性的, 或是在一定程度上简化了区系 的关系。由于缺乏详细的地理尺度上的资料和数据 分析, 制约了在生物地理分区方面的深入分析和精 细的划分，使得人们广泛地使用粗放的植被类型、 生物群落或气候类型的图来简易地划分生物地理 的次级区划(Kreft \& Jetz, 2010)。

可见，中国区系区划的工作仍然是非常不足 的，区系边界特别是次级分区的边界仍然是不清楚 的。即使是一级分区如中国植物区系古热带植物区 的边界和古地中海植物区的边界仍然需要详实的 资料进一步界定, 即便是研究得比较清晰的中国喜马拉雅森林植物亚区和中国-日本森林植物亚区 的分界线也不十分明确。中国植物区系次级分区中 的地区和亚地区，目前还缺乏详细的物种组成和分 布信息的资料，也缺乏定量的统计分析(Zhang et al, 2016b); 甚至部分区划单元的范围和特征可能需要 重新界定。因此, 植物区系区划定性的现象描述还 没有完善，还无法定量地对区系格局进行解释或对 形成机制进行深入研究。

阐明中国植物区系各分布区类型的形成和起 源是揭示中国植物区系地理格局形成的基础。通常 相同分布区类型应该有着相似的形成历史、形成机 制, 也经历过相同或相似的地质环境变迁, 因此,
研究分布区形成可回答植物区系来源、形成时间和 散布机制等生物地理学中的重要理论问题。但迄今 为止，除了东亚-北美间断分布类型外(Wen et al, 2016), 对其他中国植物区系各分布区类型的起源 和形成的研究还不多。此外, 虽然随着分子系统和 生物地理学等学科的快速发展, 中国植物区系中已 有至少 300 个不同分类阶元的类群开展了分子生物 地理学或历史生物地理学的研究, 为揭示中国植物 区系的来源、传播途径、起源时间以及同地质环境 的变迁提供了重要的证据。但相对于中国接近3,000 属来说，也仅是 $1 / 10$ 。还需要进行多类群、多层次、 多方法、多学科的综合研究。

\section{3 发展趋势}

\section{1 在区系调查方面, 注重植物信息数据的完整 和精细收集}

植物区系的调查采集(包括资料的收集)在不断 发展的生物学中将继续发挥重要的作用(Wen et al, 2015)。但目前中国仍然有许多调查薄弱的区域，有 些地区甚至没有植物区系的调查, 如藏东南-云南 边境部分地区以及金沙江、雅狵江、怒江部分河谷 地区，最近在雅聋江还发现有古老的特有物种雅聋 江冬麻豆(Salweenia bouffordiana) (Yue et al, 2011) 等，甚至在区系调查较为密集的神农架地区，近年 还发现古老的特有属征镒麻属(Deng et al, 2013)。在 植物区系的野外调查上，除仍需秉承传统的标本采 集及完整的生境及性状信息记录外，还应加强对植 物数字化信息, 如GPS、海拔、生境、图片及DNA 样品等资料的全面搜集。过去由于大多数标本采集 记录缺乏GPS信息，制约了植物区系定量区划工作 的开展。GPS及海拔信息对区系区划的意义重大, 在这两类信息的基础上，可以通过DIVA GIS从气候 图层中分别提取不同分布区植物在 3 个时期即末次 间冰期(the Last Interglacial, LIG; c. 120-140 ka)、末 次冰盛期(Last Glacial Maximum, LGM; c. $21 \mathrm{ka}$ )和 现今(Current； c. 1950-2000)的19个生物气候因子， 进而可以分析不同分布类型植物在气候因素方面 的差异，还可以通过生态位模拟方法推测不同植物 的历史潜在分布区，这些方法在如今的生态学和居 群遗传学研究中都得到了广泛的应用(Smith \& Donoghue, 2010; Wang et al, 2015; Luo et al, 2016), 而所有的这些都需要精确的GPS采集记录。因此, 
今后还需要对标本记录资料或调查信息不全的物 种进行原产地的补充调查和信息(GPS、图片等)的 采集。

此外, 通过系统和深入的区系调查和采集还会 获得新的分布信息, 如有些植物在原产地已经灭 绝, 但可能在其他区域发现。如富宁油果樟 (Syndiclis fooningensis) 在模式产地富宁灭绝, 但在 邻近的那坡县有发现, 刺䒓参(Echinocodon draco) 在模式产地湖北省郧西县已经灭绝, 但在陕西安康 县发现有少量居群(Hong, 2016)。

\section{2 加强分类学特别是地区植物志或专著的编写} 和修订, 进一步核实物种名录, 提高物种数据的准 确度

目前植物区系数据库主要来源于已经出版的 植物志书、专著和各类植物名录以及植物标本馆的 标本(特别是分布的详细数据), 虽然《中国植物志》、 Flora of China以及地方植物志和名录已经提供了 大量的植物区系的信息和分布数据, 但由于对物种 概念的理解不同、异名、裸名物种鉴定不够准确以 及分类学的处理和分类群归属的变更、调查的不足, 加上录入的标本数据鉴定的准确性不足等, 植物区 系的深入研究特别是大尺度的物种多样性准确分 析受到了很大的影响。今后植物分类学家的一个重 要任务就是提升标本鉴定的准确率、规范物种名 称、提高植物区系数据库物种信息的准确率。

\section{3 构建各类信息齐全的植物区系大数据, 并且}

\section{利用数据库信息对植物区系进行分析}

近年来各类物种数据不断增加, 利用数据库中 的物种信息可以: (1)对植物区系的分布格局现象进 行精确描述, 并探讨其影响因素; (2)探讨区系特有 性格局的成因, 确定特有类群的分布格局并界定特 有中心成因以及提出保护对策; (3)为植物区系分布 和分异边界提供精确的描述; (4)获取植物潜在的进 化信息(如短时间尺度的表型变化等)。因此, 信息齐 全的数据库建设对今后植物区系的研究至关重要。 目前国内已经有了一些利用物种信息数据库进行 的研究, 如Mao等(2013)分析了青藏高原物种丰富 度格局, 发现青藏高原物种的丰富度集中在南部和 东部区域, 这与这些区域的环境异质性、水分及能 量的变化等有密切的关系。Zhang等(2009a)通过对 横断山区一些重要类群的物种丰富度进行的梯度 分析, 提出了以北纬 $29^{\circ}$ 线为横断山植物区系的南
北分界线; 并且发现海拔3,000-4,000 m 是物种丰富 度、特有度最高的范围, 也是植物区系剧烈分化的 场所(Zhang et al, 2009b); Zhang等(2016a)通过对青 藏高原植物区系进行网格划分, 定量地对青藏高原 植物区系进行了分区研究。此外，对区系中特有类 群的分布格局和特有中心的定量分析和确定如 López-Pujol等(2011)、Huang等(2011，2012)、Feng 等(2015)对中国特有类群的空间格局及成因开展了 深入的定量研究。

\section{4 与相关学科结合, 揭示植物区系地理格局的 时空演化历程}

\subsection{1 与生态学结合, 解释区系中物种分布的格局 及其相关的环境因素}

近年来, 生态学家和生物地理学家都在更大范 围中探索和解释生物地理格局或分布模式, 生物地 理学和生态学的交叉成为植物区系地理研究发展 的重要方向, 如根据系统发育推测区域中物种分布 区的形成过程，用谱系地理分析揭示遗传多样性地 理历史、物种归类以及生态位的分割、生态空间的 饱和以及区域生物区系的多样化和发生发展等 (Emerson et al, 2011; Ricklefs \& Jenkins, 2011)。与生 态学结合还体现在生物地理学和生态学在集合种 群(metapopulation)、集合群落(metacommunity)、区 域群落等尺度上均采用共同的研究方法和技术手 段来探讨不同尺度区系形成的时空进程(Jenkins \& Ricklefs, 2011)。因此, 在未来植物区系的研究中, 无论是在小的地区尺度还是在大的区域尺度上均 会涉及到从种群到群落以及更大范围的植物群落 或植物区系的深入探究, 并逐步从区系构成、特征 和性质等现象的定性描述, 深入到区系不同尺度的 空间构成的时间和空间进化历程以及形成机制等 机理上的解释。

随着植物区系地理学研究的深入, 需要解释为 什么一些物种会分布在一些区域而不在其他范围 中出现, 除了物种自身的散布能力外, 生态因素是 主要的限制因子。生态位模型(Ecological Niche Modeling, ENM)或物种分布模型(Species Distribution Modeling, SDM)的提出为分析物种的空间格局 提供了新方法(Soberón \& Peterson, 2005), 并已在 生物地理和生物多样性保护等领域被广泛使用(朱 耿平等, 2013)。生态位模型是整合物种分布信息(如 来自标本记录的信息), 结合气候、地形、土壤性质 
乃至物种的相互作用和生理条件等来预测物种可 能的分布区或特定需求的生态条件, 在现代植物地 理格局形成的研究中结合生态位模型来揭示大尺 度生物地理格局也是生物地理学发展的趋势(Wen et al, 2013)。例如Zhang等(2016b)利用物种分布模型 (SDM) 将中国植物区系分为 5 个主要的植物地理区 域和11个亚区域, 补充和修订了原有的植物地理分 布，同时还发现年降水量是影响植物区系丰富度的 核心因素。

\subsection{2 与系统发育结合, 探讨植物区系的进化历史 和亲缘关系}

(1)探讨区系的起源和形成时间。近年来, 越来 越多的研究者开始将系统发育信息整合到不同尺 度的区系地理或生态地理的研究中 (Emerson \& Gillespie, 2008), 用以探讨区系的系统发育多样性 (phylogenetic diversity)及区系的进化潜力。因此, 在 大数据以及生态学等学科融合的基础上, 可结合系 统发育信息对不同区域的植物区系进行系统发育 多样性指数的计算及差异性比较, 从而推测不同区 域间区系的相似性、差异性及进化关系(Kreft \& Jetz, 2010)。分子进化树包含生物进化关系的重要信 息, 不仅可以准确反映某一区系内某一类群与其姐 妹群的系统发育关系, 推测该生物类群与其姐妹群 的分化时间, 还可以通过结合生物地理学的研究来 推测类群可能的地理来源。这样能揭示植物区系的 分化时间、形成历史、空间格局的进化历程以及植 物区系的进化潜力。最近, Swenson和Umaña (2014) 提出了植物系统发育区系学 (phylofloristics) 的概 念, 利用区系中多个系统发育树来评估岛屿特有的 植物区系格局和系统发育区系的相似性, 并根据比 较特有和非特有类群的结果来分析这些相似性与 空间和环境距离等因素的关系。近年来, 越来越多 的区系进化历史的研究开始注重与系统发育的研 究相结合。Verboom等(2009)结合系统发育关系估测 了以Fynbos和Succulent karoo两种植物群落为代表 的南非开普植物区系的起源时间及分化时间, 该研 究表明, Succulent karoo区系是中新世后才发展起 来的与气候波动联系紧密的年轻区系, 而Fynbos区 系尽管有些类群的起源可以追溯到渐新世, 但是绝 大多数类群的起源和分化时间都很年轻。Hoorn等 (2010)的研究表明, 有着最为丰富的热带植物多样 性的亚马逊植物区是更新世以前在安第斯山脉隆
升的背景下形成的年轻的植物区系。加利福尼亚现 代植物区系的形成主要是起源于北极-第三纪和古 地中海第三纪成分和外来迁移的类群，进化历程中 灭绝率低, 也是一个重要的避难所 (Lancaster \& Kay, 2013)。Crispand和Cook (2013)基于以往发表的 85 个有关澳大利亚植物类群的系统发育的研究，提 出澳大利亚植物区系成分的主要来源并非像以往 学者认为的那样有着冈瓦纳起源的背景, 所研究类 群中只有 $45 \%$ 的类群来源于冈瓦纳大陆, 且澳大利 亚不同的植物群落有着不同的来源背景，其占优势 的旱生植物区系是中心世以来在气候变干变冷的 背景下形成的。Linder (2014)对非洲的植物区系的 研究表明, 整个非洲可以分为 6 个以不同地理分布 为中心的植物区系, 其中最古老的是低地森林 (lowland forest)植物区系, 而最年轻的热带高山植 物区系(tropic-alpine flora)是上新世和更新世在东非 火山山顶发育而成的。

此外, 随着系统发育的研究积累, 进化生物学 家们发现在进化历程中各进化支系主要的生态位 比预期的要保守，也即系统发育生态位的保守性 (phylogenetic niche conservatism)(Harvey \& Pagel, 1991)。Donoghue (2008)指出这种系统发育生态位的 保守性对群落和区域植物区系的形成有重要的作 用; 与物种就地进化出的适应机制相反, 若是物种 迁移通道存在的话，新的环境常会被缓慢迁移的物 种所占据，这些物种相关的适应机制在原来区域就 已经进化形成，而不是在新环境中进化形成。这能 更深入地理解物种的分化、灭绝和迁移等生物地理 格局的成因，如Smith和 Donoghue (2010) 通过对 Caprifolium生物地理格局的研究, 探讨了马德雷特提斯间断模式(Madrean-Tethyan disjunct)的形成 以及Hypericum生物地理进化历史的重建(Meseguer et al, 2015)等。

(2)植物区系分区的定量和精细划分。植物区系 分区一直是区系区划研究的一个重要内容(Cox, 2001)。结合系统发育的区系区划更加精细和定量, 能够客观地反映生物区系的进化历史(Holt et al, 2013)。当前，基于系统进化的区系区划的最具代表 性的研究来自于动物的区系区划。Holt等(2013)在 华莱士动物区系区划的基础上，利用Pairwise phylogenetic beta diversity的方法, 通过整合21,037种哺 乳动物、鸟类、两栖类的系统发育关系及地理分布， 
对全世界动物区系进行了重新划分, 确立了全球的 动物区系分区。植物区系区划方面, Li等(2015)通过 对云南种子植物 1,983 属的地理分布资料, 并结合 系统发育关系将云南省划分为 8 个生物地理小区, 聚为南、北两个大的地理单元。兔耳风属 (Ainsliaea)、粉花绣线菊(Spiraea japonica)复合群的 系统学及生物地理学研究也从侧面印证了东亚植 物区系中国-日本和中国-喜马拉雅地区的划分 (Zhang et al, 2006; Mitsui et al, 2008)。

(3)结合群体遗传和亲缘地理学研究, 探讨植物 区系的次级分区及避难所。近年来随着群体遗传学 和亲缘地理学的发展, 很多学者开始利用亲缘地理 学的研究方法来探讨植物区系的次级分区。

Amarilla等(2015)基于对南美过渡带 (The South American Transition Zone)的植物Munroa argentina 的亲缘地理学研究, 证实了该地区植物区系亚地区 的划分。亲缘地理学研究还为植物区系分界线形成 的时间和机制提供了依据, 区系分区上会存在着分 割某两个地区的地理分界线如田中-楷永线 (Tanaka-Kaiyong Line) (Li \& Li, 1997), Fan等(2013) 通过对Sophora davidii的亲缘地理学研究表明, 田 中一楷永线并不是由于地质活动造成的, 而是由更 新世气候和植被类型的改变所塑造。Bai等(2016)利 用Juglans section Cardiocaryon的亲缘地理学研究 揭示了在新近纪(Neogene)和更新世(Pleistocene)东 亚植物区存在一条南北分界线。

(4)与古植物及地质历史资料结合, 探讨植物区 系形成的历史进程。古植物学的相关研究为理解植 物区系的历史演变提供了依据 (Tiffney \& Manchester, 2001)。近年来, 随着越来越多的化石类 群的发表, 从大尺度上探讨植物区系的演变成为可 能。Jacques等(2013)利用整个中国已经发表的74个 地点的144个化石群对新近纪整个中国的植被进行 了重建, 并推测气候变冷及季风的变化是影响中国 不同地区植物区系演变的重要因素。Xing等(2015) 对从数据库中提取出的 5 个不同地质年代的 55 个木 本被子植物化石区系的数据进行了排序和聚类分 析, 推测了木本被子植物区系在新生代的演变。该 研究表明, 现代不同地区的木本被子植物区系的形 成是新生代以来在不同的地质年代各个地区中存 在着扩散障碍(dispersal barriers)的结果, 扩散障碍 导致了不同地区的木本被子植物区系平行进化, 同
时气候变化在木本被子植物区系的地理演化中扮 演着重要的角色(Xing et al, 2015)。

气候的变化是驱动植物区系演变的重要驱动 因素之一, 结合化石分布和气候数据的模型模拟, 为我们探寻气候变化对植物区系演变的影响提供 了可能性。Huang等(2015)利用子遗植物的分布和气 候数据的相关性分析, 认为子遗植物在新生代的历 史分布与降水有关。子遗植物在北半球曾经的广泛 分布很可能与当时的湿润气候有关, 而当前的子遗 植物的狭域分布与新生代全球变冷的背景下的气 候变干相关(Huang et al, 2015)。Hui等(2011)对天水 盆地的孢粉研究表明, 在中新世早期这一地区还有 温带性质的常绿阔叶林存在, 而自 $8.5 \mathrm{Ma}$ 之后逐步 被草原植被所代替, 并认为全球性的气候变化(干 早)是驱动这一地区区系演变的因素。

地质变迁是影响植物分布格局的重要因素, 其 中对植物区系变迁影响较大的地质变迁主要包括 海陆格局的改变以及局部地区的造山运动等 (Tiffney \& Manchester, 2001; Milne \& Abbott, 2002)。 随着地质学和生物学的不断发展, 一些研究者开始 从地质演化角度揭示某一特定区域的区系形成机 制，特别是综合地质历史、气候演变以及分子钟、 生物地理进化、分化速率等所有的信息和成果, 利 用元分析(meta-analysis)方法来研究生物区系的形 成与演变。如Favre等(2015)综合了有关青藏高原生 物多样性进化的所有成果, 结合青藏高原的地质历 史, 通过元分析重建了其生物多样性的形成和演变 历程。类似的还有Hoorn等(2010)通过结合该区域的 地质演化研究和系统发育研究, 提出了亚马逊植物 区系的形成很可能与安第斯山脉隆升及山脉隆升 引起的地域性的环境变化(地形、流域系统、气候变 化)相关。地质变迁可以促进植物区系的演变和发 展, 同样现存的植物区系分布模式又可以反映某些 特定的地质历史变迁。最近, Zhu (2016)通过比较海 南岛与越南以及我国广东广西的植物区系相似性 认为, 海南岛与越南植物区系具有更高的相似性, 并认为海南岛的起源是大陆性的, 并且至少是在始 新世时, 海南岛与越南及中国广西是相互毗邻的。

\section{4 展望}

当今的植物区系地理学的研究步入了多学科 融合交叉(生态学、系统发育、古植物及地质历史 
等)、多尺度深入(种群、类群、区系、大尺度格局 等)、综合研究分析等一个崭新的时代, 学科界限日 趋模糊; 整合分子系统发育、生态学、化石及地质 历史等多学科资料的交叉融合, 开展精细尺度的植 物区系起源与进化以及空间格局形成机制的研究, 已成为近年来新的研究热点。植物区系进一步调查 完善和全数据库构建大数据分析(数据挖掘-大数据 分析-多方法的运用), 使植物区系地理研究也逐步 由定性的现象描述进入到解释区系格局形成机制 以及区系区划的定量研究, 这成为区系地理学学科 发展的另一趋势。其中最重要的是基础物种信息数 据库的完善和信息的准确, 一方面需要植物分类学 家更深入和细致的研究和分类修订, 对植物标本进 行系统的清理和正确的鉴定, 对物种基础的数据库 进行审核; 另一方面, 需要补充完善物种的各类信 息如形态-地理、系统发育、繁殖、生态、环境、 GPS、染色体、遗传以及基因组等形成物种全息数 据库。这是植物区系地理学家面临的新的机遇和 挑战。

致谢：陈家辉博士提供相关资料，特此致谢。

\section{参考文献}

Amarilla LD, Anton AM, Chiapella JO, Manifesto MM, Angulo DF, Sosa V (2015) Munroa argentina, a grass of the South American transition zone, survived the Andean uplift, aridification and glaciations of the Quaternary. PLoS ONE, 10, e0128559.

Bai WN, Wang WT, Zhang DY (2016) Phylogeographic breaks within Asian butternuts indicate the existence of a phytogeographic divide in East Asia. New Phytologist, 209, 1757-1772.

Cao W, Fu PY, Liu SZ, Li JY, Qin ZS, Yu XH, Zhu CX (1995) Studies on the flora of the seed plants from the flora subregion of NE China Plain. Acta Botanica Yunnanica, 17(Suppl. VII), 22-31. (in Chinese with English abstract) [曹伟, 傅沛云, 刘淑珍, 李冀云, 秦忠时, 于兴华, 朱彩 霞 (1995) 东北平原植物区系亚地区种子植物区系研究. 云南植物研究, 17(增刊VII), 22-31.]

Chen LZ (ed.) Floristics and Vegetation Geography of China. Science Press, Beijing. (in Chinese) [陈灵芝主编. 中国植 物区系与植被地理. 科学出版社, 北京]

Cox CB (2001) The biogeographic regions reconsidered. Journal of Biogeography, 28, 511-523.

Crisp MD, Cook LG (2013) How was the Australian flora assembled over the last 65 million years? A molecular phylogenetic perspective. Annual Review of Ecology,
Evolution, and Systematics, 44, 303-324.

Deng T, Kim C, Zhang DG, Zhang JW, Li ZM, Nie ZL, Sun H (2013) Zhengyia shennongensis: a new bulbiliferous genus and species of the nettle family (Urticaceae) from central China exhibiting parallel evolution of the bulbil trait. Taxon, 62, 89-99.

Donoghue MJ (2008) A phylogenetic perspective on the distribution of plant diversity. Proceedings of the National Academy of Sciences, USA, 105, 11549-11555.

Emerson BC, Cicconardi F, Fanciulli PP, Shaw PJA (2011) Phylogeny, phylogeography, phylobetadiversity and the molecular analysis of biological communities. Philosophical Transactions of the Royal Society B: Biological Sciences, 366, 2391-2402.

Emerson BC, Gillespie RG (2008) Phylogenetic analysis of community assembly and structure over space and time. Trends in Ecology \& Evolution, 23, 619-630.

Fan DM, Yue JP, Nie ZL, Li ZM, Comes HP, Sun H (2013) Phylogeography of Sophora davidii (Leguminosae) across the 'Tanaka-Kaiyong Line', an important phytogeographic boundary in Southwest China. Molecular Ecology, 22, 4270-4288.

Fang RZ, Bai PY, Huang GB, Wei YG (1995) A floristic study on the seed plants from tropics and subtropics of Dian-QianGui. Acta Botanica Yunnanica, 17(Suppl. VII), 111-150. (in Chinese with English abstract) [方瑞征, 白佩瑜, 黄广宾, 韦毅刚 (1995) 滇黔桂热带亚热带(滇黔桂地区和北部湾 地区)种子植物区系研究. 云南植物研究, 17(增刊VII), 111-150.]

Favre A, Päckert M, Pauls SU, Jähnig SC, Uhl D, Michalak I, Muellner-Riehl AN (2015) The role of the uplift of the Qinghai-Tibetan Plateau for the evolution of Tibetan biotas. Biological Reviews, 90, 236-253.

Feng G, Mao LF, Sandel B, Swenson NG, Svenning JC (2015) High plant endemism in China is partially linked to reduced glacial-interglacial climate change. Journal of Biogeography, 43, 145-154.

Fu PY, Li JY, Cao W, Ding TY, Qin ZS, Liu SZ, Zhu CX (1995) Studies on the flora of the seed plants from the flora region of NE China. Acta Botanica Yunnanica, 17(Suppl. VII), 11-21. (in Chinese with English abstract) [傅沛云, 李 冀云, 曹伟, 丁托娅, 秦忠时, 刘淑珍, 朱彩霞 (1995) 东北植物区系地区种子植物区系研究. 云南植物研究, 17(增刊VII), 11-21.]

Goodwin ZA, Harris DJ, Filer D, Wood JRI, Scotland RW (2015) Widespread mistaken identity in tropical plant collections. Current Biology, 25, R1066-R1067.

Hao RM (1997) On the areal-types of the Chinese endemic genera of seed plants. Acta Phytotaxonomica Sinica, 36, 500-510. (in Chinese with English abstract) [郝日明 (1997) 试论中国种子植物特有属的分布区类型. 植物分类学报, 36, 500-510.]

Harvey PH, Pagel MS (1991) The Comparative Method in Evolutionary Ecology. Oxford University Press, Oxford. 
Holt BG, Lessard JP, Borregaard MK, Fritz SA, Araújo MB, Dimitrov D, Fabre PH, Graham CH, Graves GR, Jønsson KA, Nogués-Bravo D, Wang ZH, Whittaker RJ, Fjeldså Jon RC (2013) An update of Wallace's zoogeographic regions of the world. Science, 339, 74-78.

Hong DY (2016) A Monograph of Codonopsis and Allied Genera. Science Press, Beijing.

Hong DY, Blackmore S (2013) Plants of China: A Companion of the Flora of China. Science Press, Beijing.

Hoorn C, Wesselingh FP, ter Steege H, Bermudez MA, Mora A, Sevink J, Sanmartin I, Sanchez-Meseguer A, Anderson CL, Figueiredo JP, Jaramillo C, Riff D, Negri FR, Hooghiemstra H, Lundberg J, Stadler T, Sarkinen T, Antonelli A (2010) Amazonia through time: Andean uplift, climate change, landscape evolution, and biodiversity. Science, 330, 927-931.

Hsieh CF (2002) Composition, endemism and phytogeographical affinities of the Taiwan flora. Taiwania, 47, 298-310.

Huang JH, Chen B, Liu C, Lai JS, Zhang JL, Ma KP (2012) Identifying hotspots of endemic woody seed plant diversity in China. Diversity and Distributions, 18, 673-688.

Huang JH, Chen JH, Ying TS, Ma KP (2011) Features and distribution patterns of Chinese endemic seed plant species. Journal of Systematics and Evolution, 49, 81-94.

Huang YJ, Jacques FMB, Su T, Ferguson DK, Tang H, Chen WY, Zhou ZK (2015) Distribution of Cenozoic plant relicts in China explained by drought in dry season. Scientific Reports, 5,14212.

Hui Z, Li J, Xu Q, Song C, Zhang J, Wu F, Zhao Z (2011) Miocene vegetation and climatic changes reconstructed from a sporopollen record of the Tianshui Basin, NE Tibetan Plateau. Palaeogeography, Palaeoclimatology, Palaeoecology, 308, 373-382.

Jacques FMB, Shi G, Wang WM (2013) Neogene zonal vegetation of China and the evolution of the winter monsoon. Bulletin of Geosciences, 88, 17.

Jenkins DG, Ricklefs RE (2011) Biogeography and ecology: two views of one world. Philosophical Transactions of the Royal Society B: Biological Sciences, 366, 2331-2335.

Kreft H, Jetz W (2010) A framework for delineating biogeographical regions based on species distributions. Journal of Biogeography, 37, 2029-2053.

Lancaster LT, Kay KM (2013) Origin and diversification of the California flora: re-examining classic hypotheses with molecular phylogenies. Evolution, 67, 1041-1054.

Li R, Kraft NJB, Yang J, Wang YH (2015) A phylogenetically informed delineation of floristic regions within a biodiversity hotspot in Yunnan, China. Scientific Reports, 5, 9396.

Li XW (1995a) A floristic study on the seed plants from tropical Yunnan. Acta Botanica Yunnanica, 17, 115-128. (in Chinese with English abstract) [李锡文 (1995a) 云南热带 种子植物区系. 云南植物研究, 17, 115-128.]

Li XW (1995b) A floristic study on the seed plants from the region of Yunnan Plateau. Acta Botanica Yunnanica, 17,
1-14. (in Chinese with English abstract) [李锡文 (1995b) 云南高原地区种子植物区系. 云南植物研究, 17, 1-14.]

Li XW, Li J (1997) The Tanaka-Kaiyong Line_an important floristic line for the study of the flora of East Asia. Annals of the Missouri Botanical Garden, 84, 888-892.

Li XW, Li J (1993) A preliminary floristic study on the seed plants from the region of Hengduan Mountain. Acta Botanica Yunnanica, 15, 217-231. (in Chinese with English abstract) [李锡文, 李捷 (1993) 横断山脉地区种子植物 区系的初步研究. 云南植物研究, 15, 217-231.]

Linder HP (2014) The evolution of African plant diversity. Frontiers in Ecology and Evolution, 2, 38.

Liu FX, Liu SL, Yang ZB, Hao RM, Yao J, Huang ZY, Li N (1995) A floristic study on the seed plants from the region of East China. Acta Botanica Yunnanica, 17(Suppl. VII), 93-110. (in Chinese with English abstract) [刘昉勋, 刘守 炉, 杨志斌, 郝日明, 姚金, 黄致远, 李宁 (1995) 华东 地区种子植物区系研究. 云南植物研究, 17(增刊VII), 93-110.]

Liu JQ, Sun YS, Ge XJ, Gao LM, Qiu YX (2012) Phylogeographic studies of plants in China: advances in the past and directions in the future. Journal of Systematics and Evolution, 50, 267-275.

Liu YX (1995) A study on origin and formation of the Chinese desert floras. Acta Phytotaxonomica Sinica, 33, 131-143. (in Chinese with English abstract) [刘媖心 (1995) 试论荒 漠地区植物区系的发生与形成. 植物分类学报, 33, 131-143.]

López-Pujol J, Zhang FM, Sun HQ, Ying TS, Ge S (2011) Centres of plant endemism in China: places for survival or for speciation? Journal of Biogeography, 38, 1267-1280.

Lu AM (1999) The Geography of Spermatophytic Families and Genera. Science Press, Beijing. (in Chinese) [ 路安民 (1999) 种子植物科属地理. 科学出版社, 北京.]

Luo D, Yue JP, Sun WG, Xu B, Li ZM, Comes HP, Sun H (2016) Evolutionary history of the subnival flora of the Himalaya-Hengduan Mountains: first insights from comparative phylogeography of four perennial herbs. Journal of Biogeography, 43, 31-43.

Ma JS (2011) The Outline of Taxonomic Literature of Eastern Asian Higher Plants. Higher Education Press, Beijing. (in Chinese) [马金双 (2011) 东亚高等植物分类学文献概览. 高等教育出版社, 北京.]

Mao LF, Chen SB, Zhang JL, Hou YH, Zhou GS, Zhang XS (2013) Vascular plant diversity on the roof of the world: spatial patterns and environmental determinants. Journal of Systematics and Evolution, 51, 371-381.

Meseguer AS, Lobo JM, Ree R, Beerling DJ, Sanmartín I (2015) Integrating fossils, phylogenies, and niche models into biogeography to reveal ancient evolutionary history: the case of Hypericum (Hypericaceae). Systematic Biology, 64, 215-232.

Milne RI, Abbott RJ (2002) The origin and evolution of Tertiary relict floras. Advances in Botanical Research, 38, 
281-314.

Mitsui Y, Chen ST, Zhou ZK, Peng CI, Deng YF, Setoguchi H (2008) Phylogeny and biogeography of the genus Ainsliaea (Asteraceae) in the Sino-Japanese region based on nuclear rDNA and plastid DNA sequence data. Annals of Botany, 101, 111-124.

Pan XL, Dang RL, Lv GH, Gu FX, Jiang XC, Wu GH, Shen GM, Chang SL, Wei Y (2003) Plant Floristic Geography and Its Resources Utilization in Arid Desert Area, Northwest China. Science Press, Beijing. (in Chinese) [潘晓 玲, 党荣理, 吕光辉, 顾峰雪, 姜孝成, 伍光和, 沈观冕, 常顺利, 魏英 (2003) 西北干旱荒漠区植物区系地理与 资源利用. 科学出版社, 北京.]

Qi CJ, Yu XL, Xiao YT, Cao TR, Zheng Z, Yin GP (1995) A study on the flora of the seed plants from the floristic region of central China. Acta Botanica Yunnanica, 17(Suppl. VII), 55-92. (in Chinese with English abstract) [祁承经, 喻勋林, 肖育檀, 曹铁如, 郑重, 尹国萍 (1995) 华中植物区种子 植物区系的研究. 云南植物研究, 17(增刊VII), 55-92.]

Qiu YX, Fu CX, Comes HP (2011) Plant molecular phylogeography in China and adjacent regions: tracing the genetic imprints of Quaternary climate and environmental change in the world's most diverse temperate flora. Molecular Phylogenetics and Evolution, 59, 225-244.

Ricklefs RE, Jenkins DG (2011) Biogeography and ecology: towards the integration of two disciplines. Philosophical Transactions of the Royal Society B: Biological Sciences, 366, 2438-2448.

Smith SA, Donoghue MJ (2010) Combining historical biogeography with niche modeling in the Caprifolium clade of Lonicera (Caprifoliaceae, Dipsacales). Systematic Biology, 59, 322-341.

Soberón J, Peterson AT (2005) Interpretation of models of fundamental ecological niches and species' distributional areas. Biodiversity Informatics, 2, 1-10.

Song ZC, Li HM, Zheng YH, Liu GW (1983) Miocene floristic region of China. In: Palaeobiogeographic Provinces of China (ed. Editorial Commitee of Paleontology Basic Theory Book Series), pp. 178-184. Science Press, Beijing. (in Chinese) [宋之琛, 李浩敏, 郑亚惠, 刘耕武 (1983) 我国中新世植物区系。见：中国古生物地理区系(编著： 古生物学基础理论丛书编委会), pp. 178-184. 科学出版 社, 北京.]

Swenson NG, Umaña MN (2014) Phylofloristics: an example from the Lesser Antilles. Journal of Plant Ecology, 7, $166-175$

Takhtajan A (1986) Floristic Regions of the World. University of California Press, Berkeley, CA.

Tao JR (1992) The Tertiary vegetation and flora and floristic regions in China. Acta Phytotaxonomica Sinica, 30, 25-43. (in Chinese with English abstract) [陶君容 (1992) 中国第 三纪植被和植物区系历史及分区. 植物分类学报， 30 , 25-43.]

Tao JR (2000) The Evolution of the Late Cretaceous-Cenozoic
Floras in China. Science Press, Beijing. (in Chinese) [陶君 容 (2000) 中国晚白严世至新生代植物区系的发展与演 变. 科学出版社, 北京.]

Tiffney BH, Manchester SR (2001) The use of geological and paleontological evidence in evaluating plant phylogeographic hypotheses in the Northern Hemisphere tertiary. International Journal of Plant Sciences, 162, S3-S17.

Verboom GA, Archibald JK, Bakker FT, Bellstedt DU, Conrad F, Dreyer LL, Forest F, Galley C, Goldblatt P, Henning JF, Mummenhoff K, Linder HP, Muasya AM, Oberlander KC, Savolainen V, Snijman DA, Niet T, Nowell TL (2009) Origin and diversification of the Greater Cape flora: ancient species repository, hot-bed of recent radiation, or both? Molecular Phylogenetics and Evolution, 51, 44-53.

Wang HS (1992) Floristic Geography. Science Press, Beijing. (in Chinese) [王荷生 (1992) 植物区系地理. 科学出版社, 北京.]

Wang HS (1997) Floristic Geography of North China. Science Press, Beijing. (in Chinese) [王荷生 (1997) 华北植物区系 地理. 科学出版社, 北京.]

Wang HS, Zhang YL (1994a) The distribution patterns of spermatophytic families and genera endemic to China. Acta Geographica Sinica, 49, 403-417. (in Chinese with English abstract) [王荷生，张镱锂 (1994a) 中国种子植物特有科 属的分布型. 地理学报, 49, 403-417.]

Wang HS, Zhang YL (1994b) The biodiversity and characters of spermatophytic genera endemic to China. Acta Botanica Yunnanica, 16, 209-220. (in Chinese with English abstract) [王荷生, 张镱锂 (1994b) 中国种子植物特有属的多样性 和特征. 云南植物研究, 16, 209-220.]

Wang HS, Zhang YL, Huang JS, Wu ZF, Zhao SL, Wang HS, Zhang ZW, Chen YS, Zhang CL (1995) A floristic study on the seed plants in the north China region. Acta Botanica Yunnanica, 17(Suppl. VII), 32-54. (in Chinese with English abstract) [王荷生, 张镱锂, 黄劲松, 吴志芬, 赵善伦, 王 合生, 张振万, 陈彦生, 张春林 (1995) 华北地区种子植 物区系研究. 云南植物研究, 17(增刊VII), 32-54.]

Wang ZW, Chen ST, Nie ZL, Zhang JW, Zhou Z, Deng T, Sun $\mathrm{H}$ (2015) Climatic factors drive population divergence and demography: insights based on the phylogeography of a riparian plant species endemic to the Hengduan Mountains and adjacent regions. PLoS ONE, 10, e0145014.

Wen J, Ickert-Bond SM, Appelhans MS, Dorr LJ, Funk VA (2015) Collections-based systematics: opportunities and outlook for 2050. Journal of Systematics and Evolution, 53, 477-488.

Wen J, Nie ZL, Ickert-Bond SM (2016) Intercontinental disjunctions between eastern Asia and western North America in vascular plants highlight the biogeographic importance of the Bering land bridge from late Cretaceous to Neogene. Journal of Systematics and Evolution, 54, 469-490..

Wen J, Ree RH, Ickert-Bond SM, Nie ZL, Funk V (2013) 
Biogeography: Where do we go from here? Taxon, 62, 912-927.

Wu DL, Xing FW, Ye HG, Li ZX, Chen BH (1996) Study on the spermatophytic flora of South China Sea Islands. Journal of Tropical and Subtropical Botany, 4, 1-22. (in Chinese with English abstract) [吴德邻, 邢福武, 叶华谷, 李泽贤, 陈丙辉 (1996) 南海岛屿种子植物区系地理的研究. 热 带亚热带植物学报, 4, 1-22.]

Wu SG, Yang YP, Fei Y (1995) On the flora of the apline region in the Qinghai-Xizang (Tibet) Plateau. Acta Botanica Yunnanica, 17, 233-250. (in Chinese with English abstract) [武素功, 杨永平, 费勇 (1995) 青藏高寒地区种子植物 区系的研究. 云南植物研究, 17, 233-250.]

Wu ZY (1965) The tropical floristic affinity of the flora of China. Chinese Science Bulletin, 1, 25-33. (in Chinese) [吴 征镒 (1965) 中国植物区系的热带亲缘. 科学通报, 1 , 25-33.]

Wu ZY (1987) Flora of Tibet. Science Press, Beijing. (in Chinese) [ 吴征镒 (1987) 西藏植物志. 科学出版社, 北 京.]

Wu ZY (1988) Hengduan Mountain flora and her significance. Journal of Japanese Botany, 63, 297-311.

Wu ZY (1979) The regionalization of Chinese flora. Acta Botanica Yunnanica, 1, 1-24. (in Chinese with English abstract) [吴征镒 (1979) 论中国植物区系的分区问题. 云南植物研究, 1, 1-24.]

Wu ZY (1991) The areal-types of Chinese genera of seed plants. Acta Botanica Yunnanica, 13(Suppl. IV), 1-139. (in Chinese with English abstract) [吴征镒 (1991) 中国种子 植物属的分布区类型. 云南植物研究, 13(增刊 IV), 1-139.]

Wu ZY, Lu AM, Tang YC, Chen ZD, Li DZ (2003a) The Families and Genera of Angiosperms in China: A Comprehensive Analysis. Science Press, Beijing. (in Chinese) [ 吴征镒, 路安民, 汤彦承, 陈之端, 李德铢 (2003a) 中国被子植物科属综论. 科学出版社, 北京.]

Wu ZY, Sun H (2014) The floristic geography of China. In: Floristic and Vegetation Geography of China (ed. Chen LZ). Science Press, Beijing. (in Chinese) [吴征镒, 孙航 (2014) 中国植物区系地理. 见: 中国植物区系与植被地理(编著: 陈灵芝), 3-214页. 科学出版社, 北京.]

Wu ZY, Sun H, Zhou ZK, Li DZ, Peng H (2011) Floristics of Seed Plants from China. Science Press, Beijing. (in Chinese) [吴征镒, 孙航, 周浙昆, 李德铢, 彭华 (2011) 中国种子 植物区系地理. 科学出版社, 北京.]

Wu ZY, Sun H, Zhou ZK, Peng H, Li DZ (2007) Origin and differentiation of endemism in the flora of China. Frontiers of Biology in China, 2, 125-143.

Wu ZY, Wang HS (1983) Chinese Physical Geography. Science Press, Beijing. (in Chinese) [吴征镒, 王荷生 (1983) 中国自然地理——植物地理. 科学出版社, 北京.] Wu ZY, Wu SG (1998) A proposal for a new floristic kingdom (realm): the E. Asiatic Kingdom, its delineation and characteristics. In: Floristic Characteristics and Diversity of East Asian Plants (eds Zhang AL, Wu SG). China Higher Education Press, Beijing; Springer-Verlag, Berlin Heidelberg.

Wu ZY, Zhou ZK, Li DZ, Peng H, Sun H (2003b) The areal-types of the world families of seed plants. Acta Botanica Yunnanica, 25, 245-257. (in Chinese with English abstract) [吴征殓, 周浙昆, 李德铢, 彭华, 孙航 (2003b) 世界种子植物科的分布区类型系统. 云南植物研究, 25 , 245-257.]

Wu ZY, Zhou ZK, Sun H, Li DZ, Peng H (2006) The Areal-Types of Seed Plants and Their Origin and Differentiation. Yunnan Science and Technology Press, Kunming. (in Chinese) [吴征镒, 周浙昆, 孙航, 李德铢, 彭华 (2006) 种子植物分布区类型及其起源与分化. 云 南科技出版社, 昆明.]

Xing FW, Li ZX, Ye HG, Chen BH, Wu DL (1993) A study on the floristic plant geography of Xisha Islands, South China. Tropical Geography, 13, 250-257. (in Chinese with English abstract) [邢福武, 李泽贤, 叶华谷, 陈丙辉, 吴德邻 (1993) 我国西沙群岛植物区系地理的研究. 热带地理, 13, 250-257.]

Xing FW, Wu DL, Ye HG, Li ZX, Chen BH, Li TH (1996) Flora of Nansha Islands and Their Adjacent Islands. China Ocean Press, Beijing. (in Chinese) [邢福武, 吴德邻, 叶华 谷, 李泽贤, 陈丙辉, 李泰辉 (1996) 南沙群岛及其邻近 岛屿植物志. 海洋出版社, 北京.]

Xing YW, Gandolfo MA, Linder HP (2015) The Cenozoic biogeographical evolution of woody angiosperms inferred from fossil distributions. Global Ecology and Biogeography, 24, 1290-1301.

Yang WJ, Ma KP, Kreft H (2014) Environmental and socio-economic factors shaping the geography of floristic collections in China. Global Ecology and Biogeography, 23, 1284-1292.

Yin LK (1997) Diversity and ex situ conservation of plants in the desert region of temperate zone in China. Chinese Biodiversity, 5, 40-48. (in Chinese with English abstract) [尹林克 (1997) 中国温带荒漠区的植物多样性及其易地 保护. 生物多样性, 5, 40-48.]

Ying TS (1994) An analysis of the flora of Qinling Mountain region: its nature, characteristics and origins. Acta Phytotaxonomica Sinica, 32, 389-410. (in Chinese with English abstract) [应俊生 (1994) 秦岭植物区系的性质、 特点和起源. 植物分类学报, 32, 389-410.]

Ying TS (1996) Areography of the endemic genera of seed plants in China. Acta Phytotaxonomica Sinica, 34, 479-485. (in Chinese with English abstract) [应俊生 (1996) 中国种 子植物特有属的分布区学研究. 植物分类学报, 34 , 479-485.]

Ying TS, Chen ML (2011) Phytogeography of China. Science Press, Beijing. (in Chinese) [应俊生, 陈梦玲 (2011) 中国 植物地理. 科学出版社, 北京.] 
Yue XK, Yue JP, Yang LE, Li ZM, Sun H (2011) Systematics of the genus Salweenia (Leguminosae) from Southwest China with discovery of a second species. Taxon, 60, 1366-1374.

Zhang DC, Boufford DE, Ree RH, Sun H (2009a) The 29 degrees $\mathrm{N}$ latitudinal line: an important division in the Hengduan Mountains, a biodiversity hotspot in southwest China. Nordic Journal of Botany, 27, 405-412.

Zhang DC, Ye JX, Sun H (2016a) Quantitative approaches to identify floristic units and centres of species endemism in the Qinghai-Tibetan Plateau, south-western China. Journal of Biogeography, 43, 2465-2476.

Zhang DC, Zhang YH, Boufford DE, Sun H (2009b) Elevational patterns of species richness and endemism for some important taxa in the Hengduan Mountains, southwestern China. Biodiversity and Conservation, 18, 699-716.

Zhang HD (1980) The origin and development of the Cathaysian flora. Acta Scientiarum Naturalium Universitatis Sunyatseni, 19, 89-98. (in Chinese with English abstract) [张宏达 (1980) 华夏植物区系的起源与发展. 中山大学 学报自然科学版, 19, 89-98.]

Zhang HD (1994) Another theory on the origin and development of the Cathaysian flora. Acta Scientiarum Naturalium Universitatis Sunyatseni，33，1-9. [张宏达 (1994) 再论华夏植物区系的起源. 中山大学学报(自然科 学版), 33, 1-9.]

Zhang MG, Slik JWF, Ma KP (2016b) Using species distribution modeling to delineate the botanical richness patterns and phytogeographical regions of China. Scientific Reports, 6, 22400
Zhang WH, Li DW, Liu GB, Xu XH (2002) The characteristic of the seed plant in Loess Plateau. Bulletin of Botanical Research, 22, 373-379. (in Chinese with English abstract) [张文辉, 李登武, 刘国涁, 徐学华 (2002) 黄土高原地区 种子植物区系特征. 植物研究, 22, 373-379.]

Zhang ZY, Fan LM, Yang JB, Hao XJ, Gu ZJ (2006) Alkaloid polymorphism and ITS sequence variation in the Spiraea japonica complex (Rosaceae) in China: traces of the biological effects of the Himalaya-Tibet Plateau uplift. American Journal of Botany, 93, 762-769.

Zhu GP, Liu GQ, Bu WJ, Gao YB (2013) Ecological niche modeling and its applications in biodiversity conservation. Biodiversity Science, 21, 90-98. (in Chinese with English abstract) [朱耿平，刘国卿，卜文俊，高玉葆 (2013) 生态 位模型的基本原理及其在生物多样性保护中的应用. 生 物多样性, 21, 90-98.]

Zhu H (2008) Distribution patterns of genera of Yunnan seed plants with references to their biogeographical significances. Advances in Earth Science, 23, 830-839. (in Chinese with English abstract) [朱华 (2008) 云南种子植物区系地理成 分分布格局及其意义. 地球科学进展, 23, 830-839.]

Zhu H (2016) Biogeographical evidences help revealing the origin of Hainan Island. PLoS ONE, 11, e0151941.

Zhu H (2017) Tropical flora of southern China. Biodiversity Science, 25, [朱华 (2017) 中国南部热带植物区系. 生物 多样性, 25, 204-217.]

(责任编委：邱英雄 责任编辑：时意专) 